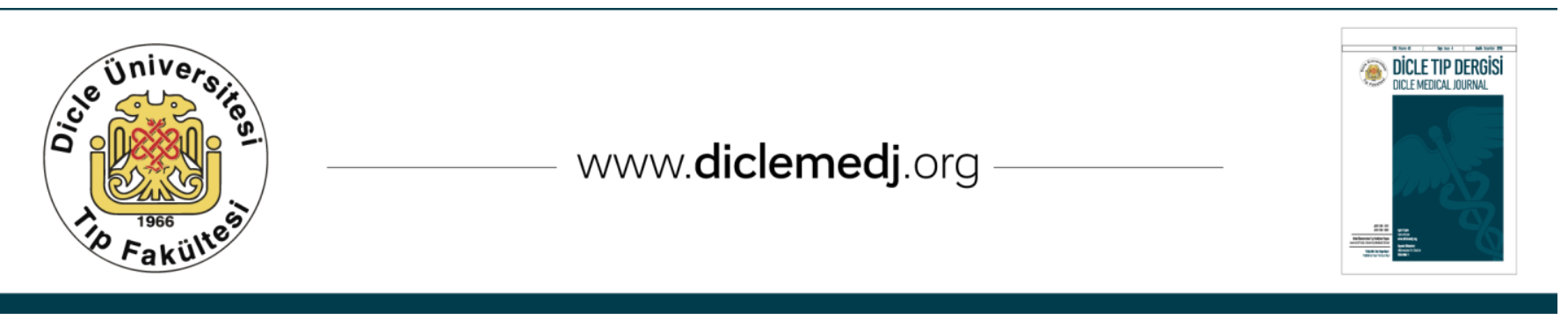

Kisa Rapor / Short Report

\title{
Güneydoğu Anadolu Bölgesi'nde Rutin Hepatit B Aşı Programının Etkisi
}

\author{
Tuncer Özekinci'1, Selahattin Atmaca², Nezahat Akpolat ${ }^{3}$, Kadri Gül ${ }^{4}$ \\ 1 Dicle Üniversitesi Tıp Fakültesi Tıbbi Mikrobiyoloji Anabilim Dalı, Diyarbakır, Türkiye ORCID: 0000-0003-3475-6604 \\ 2 Dicle Üniversitesi Tıp Fakültesi Tıbbi Mikrobiyoloji Anabilim Dall, Diyarbakır, Türkiye ORCID: 0000-0002-2730-5793 \\ 3 Dicle Üniversitesi Tıp Fakültesi Tıbbi Mikrobiyoloji Anabilim Dalı, Diyarbakır, Türkiye ORCID: 0000-0002-8653-6046 \\ 4 Dicle Üniversitesi Tıp Fakültesi Tıbbi Mikrobiyoloji Anabilim Dall, Diyarbakır, Türkiye ORCID: 0000-0002-0636-7078
}

Geliş: 08.06.2017 Revizyon: 13.07.2017 Kabul Tarihi: 27.07.2017

\section{Özet}

Diyarbakır Türkiye'nin Güneydoğu Anadolu Bölgesi'ndeki en büyük ve önemli yerleşim alanlarından biridir. 1998 yılında Sağlık Bakanlığı tarafından düzenli olarak HBV aşısı uygulanmaya başlanmıştır. Bu çalışmanın amacı, 2017 yılında HBV'li hastalarda HBV DNA düzeylerini saptamak, 2002 ve 2012 yll sonuçları ile yaș gruplarına göre karşılaştırmaktır. Hastaların HBV DNA sonuçları yedi yaş grubuna ayrılmış (0-14, 15-20, 21-30, 31-40, 41-50, 51-60, >61), 2002 ve 2012 düzeyleri ile karşılaştırılmıștır. 0-14 yaş grubunda 2017 yılında 2002 ve 2012'ye göre istatiksel olarak anlamlı bir azalma olduğu gösterilmiştir. Çalışmamız, rutin HBV aşı programının bölgede HBV enfeksiyonu riskinde özellikle 0-14 yaş grubunda yıllar içinde istatiksel olarak anlamlı bir azalma sağladığını göstermektedir.

Anahtar kelimeler: Hepatit B, aşllama, güneydoğu

\section{Effect of routine Hepatitis B vaccination Program in Southeast of Turkey}

\begin{abstract}
Diyarbakır is the largest residential area in the Southeastern Anatolia of Turkey. Routine HBV vaccination has begun to be implemented by the Ministry of Health in Turkey in 1998. The purposes of this study were to detect the levels of HBV DNA in patients with HBVin 2017, and compare the results of the years 2002 and 2012 according to age groups. HBV DNA results of patients were divided in to seven age groups $(0-14,15-20,21-30,31-40,41-50,51-60,>61)$ and for comparison of HBV DNA levels of 2002, 2012. A statistically significant decrease was seen in the number of indiviuals in 0-14 age group in 2017 compared with 2002 and 2012.
\end{abstract}

Keywords: Hepatitis B, vaccination, southeast

DOI: $10.5798 /$ dicletip.339017

Yazışma Adresi / Correspondence: Tuncer Özekinci, Dicle Üniversitesi Tıp Fakültesi Tıbbi Mikrobiyoloji A:D. 21280 Diyarbakır, Türkiye e-mail: tozekinci@gmail.com 


\section{GİRIŞ}

Diyarbakır Türkiye'nin Güneydoğu Anadolu Bölgesi'ndeki en büyük yerleşim alanlarından olup kırsal ve kentsel göç çok yaygındır. Artan nüfus, alt yapı eksikliği, genç nüfusun yüksekliği ve kişisel hijyen yetersizliği Hepatit B prevalansında potansiyel artışa neden olabilir.

2011 yllında yapılan geniş kapsamlı bir derlemede ülkemizde HBs Ag seroprevalansı Ege-Marmara Bölgeleri'nde \%3,47, Orta Anadolu-Akdeniz -Karadeniz Bölgeleri'nde $\% 4,86$ ve Doğu ve Güneydoğu Anadolu Bölgeleri'nde \%6,72 olarak tespit edilmiştir ${ }^{1}$.

Türkiye'deki seroprevalansdaki bölgesel farklılıklar sosyoekonomik yapı, yaşam şekilleri, alt yapı ve sağlık hizmetlerine erişim farklılıklarından kaynaklanmaktadır.

2004 yılında, bölgemizde yapılan geniş kapsamlı bir çalışmada, bölgemizde HBs ag seroprevalansı kırsal alanda \%8,2, kentsel alanda \%6,2 olarak saptanmıştır². Bu sonuçlar bölgemizdeki sonuçlarla birlikte uyumlu olmakla birlikte Türkiye'nin diğer bölgelerinden daha yüksektir.

1998 yılında Sağlık bakanlığı tarafından tüm çocuklara ve risk gruplarına aşı uygulanmaya başlanmıştır. Aşılama sonrası dönemde yaygınlık oranlarının bulunması, aşılama öncesi yapılan çalışmalarla anlamlı kıyaslamalar yapmamızı sağlar.

$\mathrm{Bu}$ çalışmanın amacl, 2017 yllında HBV'li hastalarda HBV DNA düzeylerini saptamak, 2002 ve 2012 yılı sonuçları ile yaş gruplarına göre karşlaştırmaktır.

\section{YÖNTEMLER}

Çalışmaya HBV DNA sonuçları pozitif olarak bulunan 539 hepatit B'li hasta dahil edilmiştir. Hastaların HBV DNA sonuçları yedi yaș grubuna ayrılmıştır $(0-14,15-20,21-30,31-40$, 41-50, 51-60, >61). HBV DNA düzeyleri gerçek zamanlı PCR ile tespit edilmiştir (AmpliPrep/COBAS COBAS Taqman HBV Test v.2 Roche Moleküler Systems, USA).

\section{BULGULAR}

2017 yılında elde edilen sonuçları yaş gruplarına ve HBV DNA düzeylerine göre sinIIflandırılması tablo 1 de gösterilmiştir 2002, 2012 ve 2017 yıllarında elde edilen farklı yaş gruplarına göre HBV DNA pozitiflik oranları tablo II de gösterilmiştir.

\section{TARTIȘMA}

Bu çalışmada 2017 yılında elde ettiğimiz HBV DNA düzeyleri ile 2002 ve 2012 yılında elde edilen düzeyler yaş gruplarına göre karşılaştırılmıştır (Tablo II). 0-14 yaş grubunda 2012 yılında 2002'ye göre anlamlı bir azalma olduğu gösterilmiştir. Diğer yaş gruplarında azalma gösterilememiştir ${ }^{3}$. Bu azalma 2017 yılında da devam etmiştir. 2002 yılında 0-14 yaş grubunda HBV DNA pozitif bireylerin oranı $\% 18,862012$ yılında \%4,80 iken bu çalışmada $\% 2,22$ olarak saptanmıștır ${ }^{3,4}$. Özellikle 2002 ile 2017 yılları arasındaki anlamlı bir azalma olmuştur $(p<0.001)$. Ayrıca 2002 ve 2012 yıllarındaki çalışmalardan farklı olarak, bu çalışmada 15-20 yaş grubunda da istatistiki olarak anlamlı olmasada ( $\mathrm{p}>0.05)$ bir azalma eğilimine girdiği görülmektedir $(2002,2012$ ve 2017 yıllarında sirasıyla $\% 10,53, \% 11,40$ ve $\% 8,16)$.

Sonuç olarak 20 yıla yakın süredir güvenli ve etkili bir aşı aşı uygulanmasına rağmen HBV ciddi bir sağllk sorunu olmaya devam etmektedir. Çalışmamız, rutin HBV aşı programının bölgede HBV enfeksiyonu riskinde özellikle 0-14 yaş grubunda yıllar içinde anlamlı bir azalma sağladığını göstermektedir. Ancak erişkinlerde aynı durum söz konusu olmayıp HBV olgularının yaş gruplarına göre dağılımı göz önüne alındığında erişkin HBV aşılamalarının yaygınlaştırılması gerekli olduğu görülmüştür. 
Tablo 1: Farklı yaş gruplarına göre HBV DNA sonuçlarının dağılımı

\begin{tabular}{|c|c|c|c|c|c|}
\hline \multicolumn{6}{|l|}{ Yaş } \\
\hline Grupla & rı Hasta sayı & $1<2.43 \times 10^{5} \mathrm{IU} / \mathrm{ml}$ & $2.43 \times 10^{5}-4.86 \times 10^{6} \mathrm{IU} / \mathrm{ml}$ & $4.87 \times 10^{6}-9.72 \times 10^{7} 10 / \mathrm{ml}$ & $>9.72 \times 10^{7} 10 / \mathrm{ml}$ \\
\hline & n (\%) & n (\%) & $\mathrm{n}(\%)$ & n (\%) & n (\%) \\
\hline $0-14$ & $12(2,23)$ & $4(33,34)$ & $1(8,33)$ & $1(8,33)$ & $6(50,00)$ \\
\hline $15-20$ & $44(8,16)$ & $30(68,19)$ & $1(2,27)$ & $1(2,27)$ & $12(27,27)$ \\
\hline $21-30$ & $179(33,21)$ & $149(83,24)$ & $9(5,03)$ & $4(2,23)$ & $17(9,50)$ \\
\hline $31-40$ & $131(24,30)$ & $117(89,31)$ & $4(3,05)$ & $5(3,82)$ & $5(3,82)$ \\
\hline $41-50$ & $98(18,18)$ & $91(92,86)$ & $2(2,04)$ & $3(3,06)$ & $2(2,04)$ \\
\hline $51-60$ & $48(8,91)$ & $46(95,84)$ & $1(2,08)$ & - & $1(2,08)$ \\
\hline$>61$ & $27(5,01)$ & $25(92,60)$ & $1(3,70)$ & $1(3,70)$ & - \\
\hline Toplam & n 539 (100) & $462(85,71)$ & $19(3,53)$ & $15(2,78)$ & $43(7,98)$ \\
\hline
\end{tabular}

Tablo 2: 2002, 2012 ve 2017 yılları pozitif HBV DNA sonuçlarının yaş gruplarına göre dağılımı

\begin{tabular}{|l|l|l|l|}
\hline Yaş Grupları & \multicolumn{2}{l}{$\mathbf{2 0 0 2}$} & \multicolumn{2}{l}{$\mathbf{2 0 1 2}$} \\
\hline & n (\%) & n (\%) & n (\%) \\
\hline $0-14$ & $231(18,86)$ & $63(4,80)$ & $12(2,22)$ \\
\hline $15-20$ & $129(10,53)$ & $148(11,40)$ & $44(8,16)$ \\
\hline $21-30$ & $378(30,86)$ & $371(38,50$ & $179(33,20)$ \\
\hline $31-40$ & $236(19,27)$ & $331(25,50)$ & $131(24,30)$ \\
\hline $41-50$ & $146(11,92)$ & $232(17,90)$ & $98(18,18)$ \\
\hline $51-60$ & $56(4,57)$ & $105(8,10)$ & $48(8,09)$ \\
\hline$>61$ & $49(4,00)$ & $50(3,80$ & $27(5,00)$ \\
\hline Toplam & $1225(100)$ & $1300(100)$ & $539(100)$ \\
\hline
\end{tabular}

Çıkar Çatışması Beyanı: Yazarlar çıkar çatışması olmadığını bildirmişlerdir.

Finansal Destek: $\mathrm{Bu}$ çalışma her hangi bir fon tarafından desteklenmemiştir.

Declaration of Conflicting Interests: The authors declare that they have no conflict of interest.

Financial Disclosure: No financial support was received.

\section{KAYNAKLAR}

1. Toy M, Önder FO, Wormann T, et al. Age-and regionspecific hepatitis B prevalence in Turkey estimated using generalizedlinear mixed models: a systematic review. BMC Infectious Diseases. 2011; 11:337.
2. Dursun M, Ertem M, Yllmaz, Ş, et al. Prevalence of Hepatitis B Infection in Southeastern Region of Turkey: Comparison of Risk Factors for HBV Infection in Rural and Urban Areas. Jpn J Infect Dis. 2005; 58:15-9.

3. Ozekinci T, Atmaca S, Dal T. Effect of routine Hepatitis $B$ vaccination program in Southeast of Turkey? Comparing of the results of HBV DNA in terms of age groups for the years 2002 and 2012. Centr Eur J Immunol. 2014; 39:122-3.

4. Ozekinci T, Ozerdem N, Atmaca S, Elçi S. Distribution of HBV DNA according to age group in the Diyarbakir Region (Southeast Turkey). J of Infect. 2003; 46:145. 